\title{
Danske meningsdannere om køn og kulturel mangfoldighed
}

Helene Pristed Nielsen Post Doc, FREIA Center for Kønsforskning, Aalborg Universitet.

Med udgangspunkt i den feministiske kritik af Habermas' offentlighedsbegreb stiller artiklen skarpt på, hvordan kønsligestilling og kulturel mangfoldighed omtales i en række interviews med meningsdannere i den danske offentlighed. Med afsæt i deres virke i politiske partier, sociale bevægelser, tænketanke og landsdækkende aviser udtaler interviewpersonerne sig om deres opfattelser af samspillet mellem køn og kulturel mangfoldighed.

\section{Motivering}

Baggrunden for $\operatorname{artiklen}^{1}$ er en kombineret interesse for demokrati og minoritetsdeltagelse samt køn. Den er baseret på et udsnit af et datasæt indsamlet til et projekt om demokrati, offentlighed og deltagelse i EU. Mit konkrete analytiske spørgsmål er „hvordan omtales kønsligestilling i forbindelse med forskellige former for identitet blandt danske meningsdannere?“. Dette bygger på feministiske indvendinger mod Habermas' offentlighedsbegreb samt to citater af Benhabib:

In effect the contemporary global situation is creating real confrontations between cultures, languages, and nations, and if the unintended results of such real confrontations is to impinge upon the lives of others, then we have a pragmatic imperative to understand each other and to enter into a cross-cultural dialogue

(Benhabib 2002, 36, original kursivering).

The claims of cultures to retain their individuality [...] can be realized only through risky dialogues with other cultures that can lead to estrangement and contestation as well as comprehensive and mutual learning (Benhabib 2002, xiv).
Med inspiration herfra er tanken, at det danske samfund muligvis står overfor et "pragmatisk imperativ“ om at indlade sig på „risikovillige samtaler“ om køn og kulturel mangfoldighed. Denne normative tanke kan man tilslutte sig eller ej. Uagtet er det interessant at analysere, hvorvidt sådanne risikovillige samtaler har empirisk grobund. Derfor præsenterer og diskuterer jeg udtalelser fra 14 danske meningsdannere om deres syn på samspillet mellem køn og kulturel mangfoldighed. Disse udsagn bruges til at diskutere relevansen af den feministiske kritik af Habermas' offentlighedsbegreb.

\section{Teoretisk baggrund: Den feministiske kritik af Habermas' offentlighedsbegreb}

Kort opsummeret leder den feministiske kritik af Habermas' offentlighedsbegreb frem til flere elementer, der kan tages højde for i forhold til at designe empiriske studier af demokratisk deltagelse (Pristed Nielsen 2009a), heriblandt:

- Der er brug for en heterogen opfattelse af den offentlige sfære (Fraser 1990, Benhabib 1996 og 2002)

- Politiske analyser bør have et bredt begreb om politikområder (Fraser 1990, Young 2000)

- Køn og andre typer af identitets-kategorier fungerer som vigtige organiserende principper i det sociale liv, og er derfor også relevante i sociale analyser (Benhabib 2002, Phillips 2007)

Samlet giver disse pointer potentielt set anledning til en gennemgribende overvejelse af hvordan man kan/bør studere demokrati og deltagelse. På denne basis kunne man undersøge utallige former for debatter i forskellige dele af samfundet, blandt grupper, der identificerer sig på forskellig vis, alt sammen relativt til det aktuelle emne. Der tegner sig ikke noget klart billede af hvilken tilgangsvinkel, der samlet kunne tage højde for de feministiske indvendinger mod Habermas' model for offentlig deliberation. 
Udfordringen kunne angribes ved at fremhæve Benhabibs pointe om, at kvinder og børns status inden for grupper kan betragtes som en lakmusprøve „The status of women and children is a litmus test for multiculturalist aspirations and their theoretical defenders" (2002, 80). En sådan tilgangsvinkel tilsiger, at man i analyser af offentlige debatter om kulturel mangfoldighed forsøger at fokusere på hvor kvinderne befinder sig, hvorledes forskellige emner evt. tillægges et kønsperspektiv, og om der er tegn på intersektionelle tilgange i disse debatter. „Intersektionalitet" sigter her på en identitetsforståelse, der tager afsæt $i$, at det sociale liv samt dertil knyttede politik-områder og offentlige sfærer, i praksis er karakteriseret ved individers samtidige og forskellige identiteter.

„Intersektionalitet“ er ikke en teori men et begreb, der bl.a. kan bidrage til at forfine empiriske analyser med interesse i hvordan identiteter omtales. Intersektionalitet kan derfor opfattes som et metodisk greb, der bidrager til at tage højde for de forskellige indvendinger mod Habermas' offentlighedsbegreb - herunder at identitetskategorier er relevante i sociale analyser og dermed i analyser af offentlige debatter. Begrebet blev introduceret af Crenshaw og diskuteres bl.a. i artiklen 'Mapping the Margins: Intersectionality, Identity Politics, and Violence Against Women of Color' (1991), hvori hun påviser, hvordan racisme og kønsdiskrimination påvirker hinanden i folks hverdag, men sjældent i feministisk og antiracistisk diskurs og praksis.

Crenshaw argumenterer som følger: „because of their intersectional identity as both women and people of color within discourses that are shaped to respond to one or the other, the interests and experiences of women of color are frequently marginalized within both" (Crenshaw 1991, 1244). I lighed med Crenshaws pointe, er tanken at det er vigtigt at undersøge om diskurser udelukker eller inkluderer væsentlige aspekter af folks levede identiteter. Jeg vil derfor bruge en intersektionel tilgang, i den forstand at jeg analyserer hvordan køn intersektes med forskellige identitetsmarkører, for at vise det spektrum af forståelser af kønsligestilling der eksisterer blandt udvalgte danske meningsdannere.

\section{Empirisk materiale: kriterier for fokus og udvælgelse}

Jeg bruger en afgrænset del af data, der bl.a. består af strukturerede interviews med prominente deltagere i den offentlige debat - i projektets terminologi omtalt som „meningsdannere“. De er udvalgt blandt politiske partier, sociale bevægelser, de trykte medier samt tænketanke. Alt i alt har det danske hold ${ }^{2}$ lavet 55 interviews i 14 organisationer. Interviews der handler om mangfoldighed, udvalgte europæiske politik-felter og den europæiske offent- lighed. Fokus er her indsnævret til hvordan køn omtales i forbindelse med andre former for identitet i udvalgte interviews. Konkret har jeg gennemsøgt materialet for udtalelser om kønsligestilling samt former for identitet. Fordi materialet er stort, medtager jeg kun interviews med den mest prominente person i hver organisation (se oversigt sidst i artiklen). Organisationerne er udvalgt med henblik på at dække politiske spektre samt repræsentere forskellige holdninger til kulturel mangfoldighed.

Jeg lavede en simpel søgning på ordet „ligestilling“ (der antages at være mere almindeligt brugt end „kønsligestilling“) i de udvalgte interviews, og i tilfælde hvor der var færre end tre resultater per interview, supplerede jeg med en søgning på „køn“. Dette blev gjort for at reducere data til en håndterbar størrelse med analytisk signifikans. Det er baseret på pointerne om, at der er brug for en heterogen opfattelse af den offentlige sfære og relevante politikområder, og at køn og andre typer af identitet fungerer som vigtige principper i det sociale liv, og derfor også er relevante i sociale analyser. Politiske partier, aviser, sociale bevægelser og tænketanke kan opfattes som mere eller mindre „stærke“ eller „svage“ offentligheder i Frasers terminologi (1990). Overført til Habermas’ ordvalg fra Between Facts and Norms kan vi se dem som stadig mere fjerne fra "centrum“ eller beslutningstagningsmagten (Habermas 1996, 354ff).

Samlet set udgør de tre parametre for dataudvælgelse en række skridt med henblik på at reducere kompleksiteten i data samtidig med, at der tages højde for en række teoretiske pointer. Således „tuner“ jeg ind på en række forskelligartede sfærer (14 forskellige organisationer), dernæst kigger jeg efter udtalelser om kønsligestilling (ved at trække svar ud fra interviews), og endelig ser jeg på disse fra et intersektionelt perspektiv (ved at kode de udtrukne svar alt efter hvilke typer af identitetsmarkører der måtte optræde).

\section{Analyse: Ligestilling +}

Efter at have gennemsøgt alle 14 interviews for ordet „ligestilling" endte jeg med en lang liste af interview-uddrag, som jeg derefter udsatte for en kodningsprocedure inspireret af Strauss og Corbins (1998) tilgang om at lade kodningskategorier opstå på baggrund af respondenters eget ordvalg. Jeg noterede tilfælde, hvor ligestilling blev omtalt i forbindelse med forskellige typer af identitet. På den baggrund opstod en række kategorier, herunder kønsligestilling, i kombination med forskellige typer af kulturopfattelser, som vil være i fokus i det følgende. Jeg vil nedenfor eksemplificere indholdet samt diskutere betydningen af samstillingerne. 


\section{Kønsligestilling og „danskhed“}

Der er mange udsagn om kønsligestilling i samspil med hvad, det vil sige at være dansk i materialet. Rolandsen Agustín (2009) har lavet en omfattende analyse af, hvordan de interviewede danske politikere (20 i alt) udtaler sig om ligestilling og dansk identitet. Hovedlinjen er her, at Danmark er førende i Europa på ligestillingsområdet. Hun påviser, at mange fra de fire politiske partier ser ligestilling som en udvikling på en skala med Danmark mere eller mindre i toppen. Ved at udvide fokus til de øvrige organisationer er det tydeligt, at dette billede stadig findes, men med interessante modifikationer og progressivt mere udfordret i de følgende eksempler. Følgende udsagn udgør en gradvis nedstigning fra den opfattelse at Danmark ligger i toppen mht. kønsligestilling. Jeg starter „øverst“ med et medlem af Ekstra Bladets redaktion: (9) „[...] nu synes jeg vi har ret høj grad af ligestilling i Danmark og i de skandinaviske lande, men jeg tror da at, vi skal ikke mange hundrede kilometer syd på, før den slipper op den der ligestilling". Udsagnet suppleres fra Den Danske Forening: (7) „Jeg tror ikke det betyder noget her [den europæiske integrations indvirkning på kønsligestilling]. Jeg ved ikke om det betyder noget i de lande i Europa hvor mænd og kvinder lever kulturelt set mere adskilt“.

Et par trin længere nede af stigen finder vi et redaktionsmedlem fra Politiken, der er knap så sikker på at kønsligestilling faktisk er opnået i Danmark: (11) „Den [europæisk integration] har allerede spillet en kæmpe stor rolle, og en kæmpe stor positiv rolle, og det er jo bemærkelsesværdigt, at den endda har formået at gøre det, for eksempel i forhold til et samfund som det danske, som jo bryster sig af, at være i front omkring ligestilling mellem kønnene“. Og sluttelig et medlem af Kvinderådet, der sætter ord på den danske kvindebevægelses dilemma om at være inkluderende og samtidig kæmpe for kvinders universelle frigørelse (Pristed Nielsen og Thun 2010, under udgivelse).

(8) [...] så har de jo et netværk som er større end det, vi ser blandt andre f.eks. danske kvinder [...] selvom man tilsyneladende isolerer sig, jamen så har man nogle styrker, som vi andre ikke har mere [...] Så er spørgsmålet om vi har sat noget til, eller om vi har vundet noget andet. Altså, jeg tror, vi har vundet noget andet, altså vi har vundet, specielt for kvindernes vedkommende har vi vundet ved at man kan gå ud og finde sig et job og forsørge sig selv og sine eventuelle børn. [...] Vi har fået mere selvstændighed, vi har fået økonomisk uafhængighed, vi har fået en større bevidsthed, aktivitet, også i forhold til rettigheder.
Den mest kritiske røst i dette trinvise billede stammer fra et medlem af $\mathrm{Ny}$ Agenda:

(13) Det er fuldstændigt hyklerisk og utroligt, at f. eks. Dansk Folkeparti, der har stemt imod al ligestillingslovgivning, nu pludselig siger at ligestilling er en dansk værdi. [...] Så man bruger altså ligestillingen til at slå indvandrerne oveni hovedet, og samtidig ikke gøre noget som helst. [...] Også når man skal lave de her indvandrerkontrakter - statsborgerskabskontrakter. Her skriver man jo også stort set under på, at her i landet slår vi ikke vores koner. Men de fleste af dem der bliver - kvinder der bliver slået injel af deres eks, de bliver jo slået injel af en blåøjet, blond mand.

Den „kontrakt“, der refereres til her, er det dokument der blev introduceret af regeringen i marts 2006, som er obligatorisk at underskrive for ansøgere af statsborgerskab i Danmark. Det indeholder bl.a. følgende formulering: „Jeg anerkender, at mænd og kvinder har lige pligter og rettigheder i Danmark, og at både mænd og kvinder skal bidrage til samfundet. [...] ligesom mænd og kvinder har den samme ret til at deltage i demokratiske processer". ${ }^{3}$ Dokumentet kan betragtes som et udtryk for regeringens officielle holdning til kønsligestilling som en dansk værdi. Som Rolandsen Agustín (2009) påviser, kan det også ses som udryk for den generelle holdning blandt mange af de interviewede politikere. Dette gør det så meget desto mere interessant at kunne konkludere på baggrund af ovenstående, at det, på trods af meget stærkt udtalte holdninger om kønsligestilling som en fait accompli i Danmark, er muligt at spore kritik og moddiskurser, hvis undersøgelsesfeltet udvides til at inkludere alternative former for offentlige sfærer - i dette tilfælde avisredaktioner, tænketanke og sociale bevægelser.

\section{Kønsligestilling og „europæiskhed“}

Givet interviewenes fokus på Europa og EU, samt at vi stiller konkrete spørgsmål om forholdet mellem kønsligestilling og normativ europæisk integration, er det næppe overraskende, at stort set alle interviews (12 ud af 14) indeholder koblinger mellem ligestilling og europæisk identitet. Her findes to typer af udtalelser; synspunkter om hvorvidt ligestilling er en særlig europæisk værdi eller ej, og diskussioner af europæisk integration som instrumentel i forhold til at fremme ligestilling i medlemsstaterne. På basis af analyser af politiker-interviews konkluderer Rolandsen Agustín, at "Gender equality is defined by most of the interviewees as a common European value in normative terms" $(2009,16)$. Dog illustrerer hendes materiale samt data medtaget her, at opfattelsen af lige- 
stilling som en europæisk værdi ikke er entydig, hverken blandt politikere eller andre. Baseret på samme logik som før, starter jeg med det synspunkt (fra Jyllands-Posten) at ligestilling er en ur-europæisk værdi:

(10) Ja, det [uligestilling mellem kønnene] er da meget ueuropæisk. Altså, det er jo en europæisk værdi med ordene fra den amerikanske forfatning ikke, at alle mennesker er lige. Det er en ur-europæisk værdi, fra Platon og Sokrates til i dag. Længere er den ikke. Dermed er alt også sagt om indvandring og køn og sådan noget.

Tanken om kønsligestilling som en „ur-europæisk værdi“ bliver dog udfordret. Her i to forskellige reaktioner på spørgsmålet: „Kan du nævne nogle ikke-europæiske eller anti-europæiske holdninger, værdier eller ideologier?", med et opfølgende spørgsmål om uligestilling mellem kønnene kunne være et eksempel. Den første reaktion er fra Danmarks Sociale Forum: (5) „[...] det [uligestilling mellem kønnene] eksisterer selvfølgelig også i Europa, både Vesteuropa og Østeuropa altså i forskellige grader af hvor kvinder er ringere stillet, men sådan som ideal i hvert fald, så vil jeg sige det er en ret udbredt europæisk ide“. Dernæst et medlem af Venstre:

\section{(3) jamen altså selvfølgelig er det [ligestilling} mellem kønnene] en europæisk værdi, men det er ikke en eksklusiv europæisk værdi. Altså, jeg mener, at det australske, new zealandske samfund, det amerikanske samfund er baseret på de samme ting. Men der er lidt en, synes jeg, ulykkelig tendens i Europa til at alt godt kommer herfra.

Disse udsagn anerkender kønsligestilling som en europxisk værdi, men afviser at Europa har et monopol på idealet. Det står i kontrast til citatet om ligestilling som en ureuropæisk værdi. I samstilling med sætningen „Dermed er alt også sagt om indvandring og køn og sådan noget" synes det at indeholde en antagelse om, at indvandrere kan lære om kønsligestiling fra europæerne.

De følgende to eksempler er medtaget, fordi de udtrykker et ligestillingsbegreb, der omfatter homoseksuelles rettigheder. Først et medlem af Politikens redaktion: (11) „Det er klart, at der er her nogle spændinger indenfor den Europæiske Union, fordi der er andre lande hvor man stadigvæk diskuterer intenst om ligestillingspræmissen nu kan gennemføres både i relation til mand-kvinde, men også i relation til homoseksuelle“. Fokus på homoseksuelles rettigheder tages også op af et medlem af Socialdemokraterne, der samtidig introducerer en gradering af danske normer i forhold til andre specifikke EU-lande: (2) „Jamen der skal man jo så bare huske, at der er Europa jo meget forskellig, ikke. Altså, i Danmark diskuterer vi nu alvorligt, om også bøsser kan få lov at adoptere. Det ender det selvfølgelig med på et tidspunkt. Prøv at tage den diskussion i Italien. Eller Rumænien eller Ungarn“.

Som eksemplerne illustrerer, kan vi diskutere, hvor vi kommer fra - i form af hvorvidt der findes noget ,ur-europæisk“" - men vi kan også diskutere, hvor vi er på vej hen i forhold til europæisk normativ integration, herunder om vi nærmer os en højere grad af ligestilling også for seksuelle mindretal. Vi spurgte specifikt til respondenternes forventninger til den europæiske normative integrations fremtidige indvirkning på kønsligestilling såvel som andre former for ligestilling. Svarene faldt indenfor et spektrum, der anså EU som en garant for ligestilling (både i Danmark og andre medlemslande), til kritiske kommentarer om at kvæle græsrodsbevægelserne ${ }^{4}$. Først et medlem af Jyllands-Postens redaktion, der primært ser EU som en garant for at fremme ligestillingen i andre lande: (10) "Jamen der tror jeg, ligesom i andre sammenhænge, kan det europæiske samarbejde i sig selv, for nogen lande løfte overlæggeren“. Hvorimod følgende udtalelse fra DIIS ser på EU's mulighed for at bidrage til kønsligestillingen i Danmark: (14) Man kan sige at i de sidste 15 år har fremskridtene på det danske arbejdsmarked på ligestilling primært været båret af EU-lovgivning". Holdningen deles i Kvinderådet: (8) „Altså hvis jeg må have lov at tage skyklapper på og sige det ud fra et kønsperspektiv, så vil jeg sige: nej hvor er jeg glad for EU. Fordi hvis ikke vi havde haft EU, og hvis ikke vi havde haft nogle direktiver på ligestillingsområdet, så er jeg bange for at det ville gå endnu langsommere i Danmark".

Som bemærkningen om skyklapperne antyder, er det væsentligt at tage højde for om respondenterne i almindelighed er EU-skeptikere eller ej. De to følgende citater er diametrale modsætninger i en evaluering af EUlovgivningens indvirkning på normer og social praksis i de enkelte medlemsstater. Begge indtager en utilitaristisk synsvinkel, men resultatet falder forskelligt ud. Her først en udtalelse fra Politiken:

(11) [J]eg synes som sagt, at den praksis som EU-domstolen har stået for, og som den fortsat videreudvikler i forhold til EU-borgeres rettigheder, yder et meget stort bidrag, som helt sikkert også langsomt vil slå igennem i de nye medlemslande, og det synes jeg er den mekanisme, hvor man så at sige mest omkostningsrealistisk kan sætte europæiske normer igennem. 
Dette står i kontrast til følgende betragtning fra et medlem af Ny Agenda:

(13) Jeg synes, det er lidt både og. Altså dem som siger, at EU har været fantastisk for ligestillingen, det mener jeg holder ikke fra en større forskningsanalyse, når det gælder de nordiske lande. Men at sige, at EU ikke har gjort noget for ligestillingen er selvfølgelig også forkert. [...] Og EU trækker jo hele tiden i retning af en retsliggørelse af problemerne. Retsliggørelse af alting. Og det kan have nogle fordele, men det kan også gøre ligesom den politiske aktivitet bag det forsvinder. [...] Så jeg mener, at hele retsliggørelsen af samfundet som sker [...] den kan være god på nogle måder, men den fører altså også til en politisk passivitet. Og jeg tror...Danmark er politisk passivt på ligestillingsområdet. [...] og så har man sovet tornerosesøvn.

På ligestillingsområdet er det en overvejelse værd, om målet skal være en „omkostningsrealistisk“, gennemførelse af normer, eller om en gennemgribende forandring bedre sikres ved at holde debatten åben. Uanset hvilket man måtte foretrække, påviser data at flere muligheder omtales, på trods af at interviewpersonerne repræsenterer et udsnit blandt danske meningsdannere, der ikke nødvendigvis har køn højt på deres dagsorden. Der er ingen entydig effekt af at køn og „europæiskhed“ intersektes i disse interviews.

\section{Kønsligestilling og islam}

Kategorien er medtaget på trods af Strauss og Corbins (1998) anbefalinger om datakodning - nemlig at kategorier bør opstå af materialet, snarere end at være bestemt af forudfattede meninger om hvad data indeholder. Jeg medtager alligevel „kønsligestilling og islam“ dels på baggrund kodning og dels, at mange danske meningsdannere bruger islam forstået som kultur og religion i flæng. Derfor følger „kønsligestilling og islam“ delvist naturligt som et interessant undersøgelsesobjekt i forbindelse med analysen af, hvordan køn intersektes med forskellige kulturopfattelser. I et af flere mulige perspektiver kan islam opfattes som en form for kulturelt standpunkt, der evt. kan kobles med holdninger til kønsligestilling. Dette er langt fra et uproblematisk perspektiv, hvilket illustreres i følgende udsagn fra et medlem af Socialdemokraterne:

(2) [N]år jeg meget bevidst indledningsvis siger at vi er multietniske men ikke multikulturelle, så er det fordi, at hvis vi var multikulturelle så skulle jeg også acceptere nogle af de kulturbaggrunde der bl.a. [har] tvangsægteskaber. [... nævner herefter visse kulturelle praksisser der ofte forbindes med islam] Og derfor er det jeg er meget præcis med at sige det der med det kulturelle, fordi jeg vil ikke give køb på de ting vi har nået på demokratiområdet, på ytringsfrihed, ligestilling mellem kønnene, på hele det seksuelle orienteringsområde. Vi er ikke nået til mål i Danmark, slet ikke [...] men vi har nået nogle skridt.

Dette er interessant, fordi det på den ene side adskiller etnicitet og kultur, men på den anden side trækker et skarpt skel mellem kulturelle praksisser såsom tvangsægteskaber i forhold til rettigheder „vi har opnået“ - et „vi“ der tilsyneladende opfattes som en etnisk dansk identitet. Således falder den sidste respondent her direkte ned i sin egen „multikulturelle fælde“, for så vidt at dansk kultur identificeres som noget, der ikke accepterer sådanne praksisser. Dette foranlediger mig til at citere Phillips: "culture needs to be treated in the more nuanced way that has become available for class and gender: that is, as something that influences, shapes and constrains behaviour, but does not determine it" $(2007,10)$.

Ovenstående illustrerer en udviskning af grænser mellem, hvad der opfattes som kulturelt betingede og religiøst betingede praksisser, hvoraf det synes uklart, hvilken type praksis kønsligestilling er - religiøs eller kulturel? Overraskende, og så meget desto mere interessant, viste det sig efter gennemgang af det udvalgte data, at selve ordet "religion“ meget sjældent nævnes i forbindelse med kønsligestilling. Der er ingen direkte koblinger i data mellem fx kristendom og kønsligestilling og kun én mellem islam og kønsligestilling. Jeg har kun noteret to direkte referencer til „religion“. Én af disse er en afvisning (fra SF) af, at religion har noget at gøre med ligestilling: (1) „Altså, det er jo ikke noget som er baseret på religion f.eks., det er baseret på nogle kulturelle mønstre, som vi havde hos os for 100 eller 200 år siden“.

Dette er en interessant udtalelse, for så vidt at denne politiker tilsyneladende forventer, at det er almindeligt at koble spørgsmål om religion og ligestilling. Denne opfattelse stemmer overens med resultater fra et tidligere studie blandt forkvinder for indvandrerkvindeorganisationer i Danmark, der konkluderede at „several women do not self-identify as Muslims on the grounds that Islam is repressive of women, whereas those who do self-identify as Muslims are cautious to explain that Islam itself is not repressive of women - apparently believing that this is a prior assumption of many" (Pristed Nielsen 2009b, 145). Faktisk viser det sig her, at antagelsen om, at Islam som sådan er kvindeundertrykkende, ikke fremstår som pro- 
minent. Det er dog en antagelse, der kommer til udtryk fra Ekstra Bladets redaktion:

(9) Ja, altså man kan sige at den muslimske påvirkning er i høj grad på tværs af ligestilling. Der er jo ikke nogen muslimske mennesker, der mener at ligestilling er et mål for deres samfundsudvikling. Så den påvirkning der kommer derfra går den forkerte vej, går på tværs af det der anses som idealet $\mathrm{i}$ - hvad skal man sige? - de mest oplyste EU-lande, hvis jeg må tillade mig at sige det.

Med ovenstående undtagelse er det en vigtig konklusion, at der i det udvalgte data ikke omtales en forbindelse mellem religion og kønsligestilling. Dette går imod forventningerne, og står i modsætning til Rolandsen Agustíns (2009) dokumentation af at religion er et (omend omdiskuteret) kriterium for afgrænsning af „dem“/,os“ i det samlede antal politikerinterviews. To forklaringer er mulige: Enten er det fordi, jeg har fokuseret på „toppen“ og kun medtaget interviews med den mest prominente person fra hver organisation, og at disse topfolk muligvis er mere bevidste om politisk korrekthed. Eller også skyldes det kodningen, hvor jeg kigger efter „ligestilling“ + former for kulturel identitet, hvorimod „religion“ måske optræder sammen med andre typer markører.

For at teste den sidste hypotese foretog jeg en ny søgning, denne gang på hhv. „muslim“/,,islam“/,tørklæde“ i de 14 udskrifter. Dette skabte et nyt datasæt, der blev udsat for en omvendt kodningsproces, sådan at jeg nu kiggede efter kønsmarkører (tørklæder blev antaget for at have en implicit kønsreference). Det gav et resultat, der stemte bedre overens med forventningen om at finde en stærk kobling mellem ligestilling og religion - men netop „religion“ eksklusivt forstået som islam. For eksempel er der en S-politiker, der udtrykker stor skepsis overfor tanken om Sharia'a domstole, fordi han ser det som problematisk i forhold til at beskytte kvinder med muslimsk baggrund der fx ønsker en skilsmisse. Formanden for Den Danske Forening afviser tanken om grupperettigheder baseret på risikoen for at begå vold mod individet ved at „lade de tilslørede kvinder i stikken, som ikke ønsker

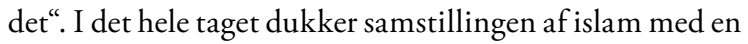
fare for undertrykkelse af kvinders rettigheder op i mange interviews, herunder en Venstrepolitiker, der svarer på et spørgsmål om dobbelt statsborgerskab:

(3) [M]it udgangspunkt er, at jeg er imod dobbelt statsborgerskab [...] Men hvis man har et fra et muslimsk land og man har dobbelt statsborgerskab, og eksempelvis en pige blev tvangsgiftet i
Pakistan, så ville det umuliggøre danske myndigheder at hjælpe den pågældende pige tilbage til Danmark, fordi hun var pakistansk statsborger.

Udtalelserne viser stor intern variation i måden at argumentere på. På den ene side er der en række argumenter, der ligner hinanden, for så vidt at de afviser tanken om kollektive rettigheder på grundlag af en bekymring for hvordan særligt kvinder risikerer at blive udsat for gruppepres og manglende individuel frihed. Disse argumenter minder om Okins (1999) spørgsmål om hvorvidt multikulturalisme udgør en særlig trussel for minoritetskvinder. Andre eksempler er forskellige fra denne type argument. Således bygger det første udsagn nedenfor på et argument ud fra majoritetens interesse (den bør ikke opleve utryghed), hvorimod det sidste synes ambivalent $\mathrm{i}$ forhold til hvis interesse, der skal tilgodeses: De kvinder der ønsker at komme i svømmehallen eller det samfund, der ønsker at undgå sociale enklaver. Begge udtalelser er fra politiske partier, først et medlem af DF: (4) „[E] ksempelvis har det været meget diskuteret med dommere - skal der være dommere, der bærer tørklæde? Og hvor tørklædet for mange i Danmark er et politisk symbol, hvor man synes det er utrygskabende“. Og dernæst Socialdemokraterne: (2) „Jeg synes for så vidt også, det er fint at en svømmeklub kan have en lukket svømmehal i en time en gang hver anden uge [...] at muslimske kvinder kan komme ud at bade, for det er den eneste måde de kommer det på“. Som det fremgår, har de interviewede meningsdannere forskellige tilgangsvinkler til hvis interesser der skal varetages, hvordan det gøres bedst, og om ligestilling overhovedet skal diskuteres i forbindelse med religiøse gruppers praksisser. På trods af diversiteten i udsagnene er det dog muligt at drage den konklusion, at effekten af at intersekte kønsligestilling med islam er, at det bliver til et spørgsmål om interessevaretagelse.

\section{Risikovillige samtaler?}

Jeg citerede i indledningen Benhabib for, at det givet den kulturelle mangfoldighed i de fleste moderne samfund er nødvendigt at indlade sig på „risikovillige samtaler“(2002, xiv), for at opnå en dybere forståelse af hinandens grænser, ønsker og behov. Gennem kodningsarbejdet blev det tydeligt at data indeholder en del referencer til tanken om debat mellem kulturer og synspunkter, og i den forstand har kodningsproceduren - der var styret af omtaler af forskellige former for kulturel identitet - spillet sammen med det teoretiske udgangspunkt i den feministiske videreudvikling af Habermas' offentlighedsbegreb. I lyset af motiveringen for artiklen er dette et væsentligt resultat, og jeg vil her redegøre for indholdet. Det første eksempel stammer fra en S-politiker, og kan i sammenligning med 
de øvrige ses som en minimalistisk tilgang til debat: (2) „Altså de der klassiske ting [ikke diskriminere i forhold til religion, etnisk baggrund, kulturbaggrund, seksuel baggrund] er jo en klar lovgivningsmæssig opgave. Så kan der være områder, som kan være mere vanskelige i forhold til lovgivning, som handler om [...at] inkludere dem i samfundsdebatten, i stedet for at ekskludere“.

Bemærk, at dette blev modsagt ovenfor af et medlem af Ny Agenda, der henviste til faren ved at gøre antidiskrimination til et juridisk spørgsmål - da den offentlige debat om emnet $\mathrm{i}$ så fald risikerede at blive forringet. Den danske kvindebevægelse kan muligvis siges at have sovet „tornerosesøvn“ i forhold til at inkludere etniske minoritetskvinder, hvilket er en skisma, som et medlem af Kvinderådet selv tager op:

(8) [D]er er nogle områder, hvor vi åbenbart ikke har en dialog, som gør, at vi forstår hinanden godt nok til at sige: jamen betyder det så at man er undertrykt, fordi man tager et tørklæde på på arbejde, eller betyder det noget andet for den enkelte der gør det? [...] Jeg tror man kan opnå meget ved at prøve at forstå noget mere, og via noget dialog. Det er ikke kun mig, altså i Kvinderådet siger vi jo: jamen altså vi bliver nødt til at have en dialog med hinanden. Vi kan jo ikke sidde her i hver sin skyttegrav og tro, at vi ved noget om hinanden. Vi bliver nødt til at have dialogen hele tiden.

Helt generelt udtrykte alle medlemmer fra de sociale bevægelser, med undtagelse af Den Danske Forening, et behov for at udvikle en debat i det danske samfund, hvoraf det følgende er et eksempel fra Demokratiske Muslimer: (6) „Så jeg synes et eller andet sted at det er ret sundt for et samfund som det danske - som har så stærke og så homogene holdninger omkring hvordan tingene bør være - engang imellem at blive mødt med noget andet der ser anderledes ud, for netop at få den nødvendige debat“. Følgende udtalelse fra Den Danske Forening står i skarp kontrast: (7) „Man skal overhovedet ikke gå i nogen som helst form for dialog, man skal bare sige: 'her i dette land er der lighed mellem kønnene'“.

Med denne sidste undtagelse, er jeg tilbage til udgangspunktet. Benhabibs teoretisk og normativt baserede påpegning af et "pragmatisk imperativ“ for „risikovillige samtaler" optræder faktisk i det empiriske materiale, hvilket tyder på at i hvert fald visse interviewpersoner - primært ledende medlemmer af de sociale bevægelser - taler om at „opnå den nødvendige dialog", med Den Danske Forening som en undtagelse. Det er i den forbindelse vigtigt at holde sig for øje, at det ovenfor præsenterede data er skabt på baggrund af interviews med meningsdannere, der i situationen er blevet bragt til at reflektere over spørgsmål om køn og mangfoldighed som de måske ikke havde levnet tanke, hvis ikke vi havde sat dem stævne. Derfor er der ikke tale om „real confrontations“ i Benhabibs forstand $(2002,36)$. Desuden fremgår det ikke af materialet, om respondenterne nødvendigvis er „risikovillige“ $i$ den forstand, at de er villige til at ændre deres egne grænser for at imødekomme andres behov. Ikke desto mindre er henvisningerne til tanken om debat betydende for så vidt, at der er tale om interviews med meningsdannere i den danske offentlighed - dog meningsdannere i en „svag“ offentlighed i henhold til. Frasers (1990) terminologi.

\section{Konklusion}

Det er tydeligt, at der bør tages en del forbehold for hvor vidtrækkende konklusioner, det er muligt at drage på baggrund af materialet. Det er en udforskning af hvordan kønsligestilling omtales i forbindelse med forskellige typer af kulturelle markører blandt 14 danske meningsdannere. Ikke desto mindre er det væsentligt at notere sig, at der i materialet er en klar samstilling mellem kønsligestilling og hhv. „danskhed“ og „europæiskhed“. En samstilling, der dog i nogen grad udfordres - særligt af de mindre „stærke“ offentligheder i hht. Frasers terminologi. I den forstand bidrager artiklen til at bekræfte relevansen af den feministiske kritik af Habermas i forhold til at have en heterogen opfattelse af offentligheder. Ved at inddrage interviewpersoner fra bl.a. sociale bevægelser og avisredaktioner, kommer der nye synspunkter frem, som ikke registreres blandt de politiske partier (se Rolandsen Agustín 2009). Desuden er det en væsentlig konklusion, at "ligestilling" i meget ringe grad optræder i materialet i forbindelse med omtaler af religiøs identitet, hvorimod en modsat søgning på „islam“, „muslim“ og „tørklæder“ resulterer i mange samstillinger med køn. Heraf konkluderer jeg, at ligestilling ikke omtales som en religiøst betinget kulturel værdi, men at islam til gengæld omtales som en religion/kultur (materialet tillader ikke nogen distinktion), der har særlig betydning for kvinders position og deltagelse i samfundet - en ret modsætningsfyldt konklusion. Herunder er det væsentligt at fremhæve, at trods stærkt differentierede holdninger er effekten af at intersekte kønsligestilling med islam, at det bliver fremstillet som et spørgsmål om interessevaretagelse. Med tanke på artiklens motivering og teoretiske udgangspunkt, er den mest interessante konklusion, at mange af meningsdannerne (særligt fra de sociale bevægelser) taler om et behov for debat i forbindelse med udtalelser om ligestilling. Det er selvfølgelig nødvendigt at påpege, at de udvalgte sociale bevægelser langt fra udgør noget repræsentativt 
udsnit, men netop er valgt med henblik på organisationer med holdninger til spørgsmål om kulturel mangfoldighed og/eller køn.

\section{Interviewoversigt}

1. SF, int.: Lise Rolandsen Agustín [LRA], d.22/12-08 + 23/2-09

2. Socialdemokraterne, int.: LRA, d.9/10+24/10-08

3. Venstre, int.: LRA og Birte Siim, d.1/9-08

4. DF, int.: LRA, d.2/12+9/12-08

5. Danmarks Sociale Forum, int.: LRA, d.25/3-09

6. Demokratiske Muslimer, int.: LRA, d-27/1-09

7. Den Danske Forening, int.: LRA og Pernille Rødkær Bundgaard [PRB], d.16/3-09

8. Kvinderådet, int.: LRA, d.23/2-09

9. Ekstra Bladet int.: PRB og Birte Siim, d.27/10-08

10. Jyllands-Posten int.: PRB, d.11/11-08

11. Politiken int.: PRB og Birte Siim, d.27/10-08

12. CEPOS, int.: Anne Skytt Gregersen [ASG] og PRB, d.19/11-08

13. Ny Agenda int.: ASG og PRB, d.6/1-09

14. DIIS, int.: ASG og PRB, d.18/11-08

\section{Referencer}

Benhabib, S 1996, Democracy and Difference, Contesting the Boudaries of the Political, Princeton University Press, New Jersey.

Benhabib, S 2002, The Claims of Culture. Equality and Diversity in the Global Era, Princeton University Press, New Jersey.

Crenshaw, KW 1991, 'Mapping the Margins: Intersectionality, Identity Politics, and Violence Against Women of Color', Stanford Law Review, Vol. 43, No. 6, pp. 1241-1299.

Fraser, N 1990, 'Rethinking the Public Sphere: A Contribution to the Critique of Actually Existing Democracy', Social Text, No. 25/26, pp.56-80.

Habermas, J 1996, Between Facts and Norms, Contributions to a Discourse Theory of Law and Democracy, Polity Press, Cambridge.

Integrationsministeriet 2006, 'Erklæring om integration og aktivt medborgerskab i det danske samfund'. Fra http://www.nyidanmark.dk/NR/rdonlyres/EC64741B-0BD9-464B-8DCF-2EA405CED223/0/integrationserklaering_dansk.pdf, [20/11 2009].

Okin, SM 1999, 'Is Multiculturalism Bad for Women?', i J Cohen, M Howard, M C Nussbaum (red.): Is Multiculturalism Bad for Women? Susan Moller Okin with respondents, Princeton University Press, Princeton.
Phillips, A 2007, Multiculturalism without Culture, Princeton University Press, Princeton.

Pristed Nielsen, H 2009a, 'Gender, Diversity and the European Public Sphere', Eurosphere Working Paper Series, no. 24, http://www. eurosphere.uib.no/knowledgebase/wpsdocs/Eurosphere_Working Paper_24_Pristed.pdf [20/11 2009]

Pristed Nielsen, H 2009b, 'Islam: a dead end for integration of female immigrants in Denmark?', i V Angeles og G Bonifacio (red.), Gender, Religion and Migration: Pathways of Integration, Lexington Books, Maryland.

Pristed Nielsen, H \& C Thun 2010, 'Multicultural Feminism in Denmark and Norway?', i Kvinder, Kon og Forskning, vol.2/3, under udgivelse.

Rolandsen Agustín, L 2009, 'It is all about the women', Eurosphere Working Paper Series, no. 22, fra http://www.eurosphere.uib.no/ knowledgebase/wpsdocs/Eurosphere_Working_Paper_22_Agustin. pdf [20/11 2009]

Strauss, A \& J Corbin 1998, Basics of Qualitative Research. Techniques and Procedures for Developing Grounded Theory, Sage Publications, London.

\section{Noter}

1 Baseret på den danske del af Eurosphere projektet - 'Diversity and the European Public Sphere: Towards a Citizens' Europe', med 16 deltagerlande. Projektet spørger hvorvidt en inkluderende europæisk offentlig sfære er mulig set i lyset af etnisk og national mangfoldighed indenfor EU og de enkelte medlemsstater. Finansieret under EUs 6. rammeprogram, se www.eurosphere.uib.no

2 Jeg er tak skyldig til Anne Skytt Gregersen, Pernille Rødkær Bundgaard, Lise Rolandsen Agustín og Birte Siim.

3 Fra http://www.nyidanmark.dk/NR/rdonlyres/EC64741B-0BD9464B-8DCF-2EA405CED223/0/integrationserklaering_dansk. pdf

4 Der er ét vigtigt citat som falder helt udenfor den typologi skitseret her, og det er en udtalelse fra Den Danske Forening, der afviste legitimiteten af at lade EU sætte normer på nogen områder overhovedet. Dette synspunkt bygger på en stærk EU-skepsis, men interessant nok bygger det også på en stærk skepsis mht. kollektive rettigheder og en bekymring for minoriteter indenfor minoriteter. Denne person henviste adskillige gange til risikoen for kvinder og børns undertrykkelse indenfor religiøse og etniske mindretal, og tilkendte sig derfor en liberal tilgangsvinkel til individers rettigheder. 